REGARDS

SUR LECONOMIE ALLEMANDE

BULLETIN ECONOMIQUE DU CRAC

\section{Regards sur l'économie allemande}

Bulletin économique du CIRAC

$101 \mid 2011$

Varia

\title{
Théorie du goût
}

SCHÜTZE I. (ed), Über Geschmack lässt sich doch streiten - Zutaten aus Küche, Kunst und Wissenschaft

\section{(2) OpenEdition}

Journals

Édition électronique

URL : http://journals.openedition.org/rea/4310

DOI : $10.4000 /$ rea.4310

ISBN : 978-2-8218-0954-3

ISSN : $1965-0787$

Éditeur

CIRAC

Édition imprimée

Date de publication : 10 juin 2011

ISSN : 1156-8992

Référence électronique

"Théorie du goût », Regards sur l'économie allemande [En ligne], 101 | juin 2011, mis en ligne le 19 septembre 2011, consulté le 22 septembre 2020. URL : http://journals.openedition.org/rea/4310 DOl : https://doi.org/10.4000/rea.4310

Ce document a été généré automatiquement le 22 septembre 2020

(C) CIRAC 


\section{Théorie du goût}

SCHÜTZE I. (ed), Über Geschmack lässt sich doch streiten - Zutaten aus Küche, Kunst und Wissenschaft

\section{RÉFÉRENCE}

SCHÜTZE I. (ed), Über Geschmack lässt sich doch streiten - Zutaten aus Küche, Kunst und Wissenschaft, Kadmos, Berlin, 2010/2011, 264 p.

1 Voici un ouvrage consacré au goût, sous ses divers aspects et horizons géographiques. Un concept aux reflets changeants, difficilement descriptible selon l'auteur. De gustibus non est disputandum... Qu'il s'agisse de gastronomie, de peinture, de l'art du tajine, des causes neurophysiologiques $d u$ «bon goût » ou de la transition du goût palatal vers le goût esthétique, ce voyage sensoriel encourage l'alliance d'une large palette de disciplines : arts plastiques, musique, physique, géographie, sciences du cinéma... Une délicieuse conclusion à la série de manifestations «Projet goût»: Revolutionen des Geschmacks, organisées en 2007 dans le cadre d'un programme à la Maison de France de Mayence. (sh) 